\title{
The Glutamate Receptor Subunit $\delta 1$ Is Highly Expressed in Hair Cells of the Auditory and Vestibular Systems
}

\author{
Saaid Safieddine and Robert J. Wenthold \\ Laboratory of Neurochemistry, National Institute on Deafness and Other Communication Disorders, National Institutes of \\ Health, Bethesda, Maryland 20892
}

\begin{abstract}
In the inner ear, fast excitatory synaptic transmission is mediated by ionotropic glutamate receptors, including AMPA, kainate, and NMDA receptors. The recently identified $\delta 1$ and $\delta 2$ glutamate receptors share low homology with the other three types, and no clear response or ligand binding has been obtained from cells transfected with $\delta$ alone or in combination with other ionotropic receptors. Studies of mice lacking expression of $\delta 2$ show that this subunit plays a crucial role in plasticity of cerebellar glutamatergic synapses. In addition, these mice show a deficit in vestibular compensation. These findings and the nature of glutamatergic synapses between vestibulocochlear hair cells and primary afferent dendrites suggest that $\delta$ receptors may be functionally important in the inner ear and prompted us to investigate the expression of $\delta$ receptors in the
\end{abstract}

cochlea and peripheral vestibular system. Reverse transcription and DNA amplification by PCR combined with immunocytochemistry and in situ hybridization were used. Our results show that the expression of $\delta 1$ in the organ of Corti is intense and restricted to the inner hair cells, whereas $\delta 1$ is expressed in all spiral ganglion neurons as well as in their satellite glial cells. In the vestibular end organ, $\delta 1$ was highly expressed in both hair cell types and also was expressed in the vestibular ganglion neurons. The prominent expression of $\delta 1$ in inner hair cells and in type I and type II vestibular hair cells suggests a functional role in hair cell neurotransmission.

Key words: cochlea; vestibular end organ; hair cells; spiral ganglion neurons; PCR; in situ hybridization; Western blot; immunocytochemistry
Auditory and vestibular stimuli are detected by hair cells in the inner ear and are transmitted to the brain by way of the auditory and vestibular nerves. Of the two types of hair cells found in the organ of Corti, inner hair cells (IHCs) and outer hair cells (OHCs), IHCs are the primary transducers of sensory information. IHCs form chemical synapses with dendrites of type I spiral ganglion neurons (SGNs) that constitute $90-95 \%$ of the SGNs. OHCs synapse on the remaining type II SGNs (Spoendlin, 1972; Berglund and Ryugo, 1987). The vestibular epithelium contains two types of sensory hair cells. Type I cells (VHCI) are flaskshaped and surrounded by an afferent nerve calyx, whereas type II (VHCII) are cylindrical and connected to small afferent endings (Wersäll and Bagger-Sjöbäck, 1974). Accumulating evidence suggests that fast excitatory synaptic transmission in the cochlea is mediated by an excitatory amino acid. The strongest evidence supporting this hypothesis is the expression of functional glutamate receptors by SGNs and their localization postsynaptic of the hair cell synapse (Bledsoe et al., 1981; Puel et al., 1991a,b; Ryan et al., 1991; Safieddine and Eybalin, 1992b; Kuriyama et al., 1994; Niedzielski and Wenthold, 1995). Although glutamate is present in hair cells, and its release from hair cells is stimulated by $\mathrm{K}^{+}$in a $\mathrm{Ca}^{2+}$-dependent manner (Jenisson et al., 1985; Bobbin et al., 1990, 1991; Kataoka and Ohmori, 1994; for review, see Eybalin, 1993), some studies suggest that a novel excitatory amino acid may be functioning at this synapse (Sewell and Morz, 1987).

Received June 25, 1997; accepted July 21, 1997.

We thank Drs. P. Seeburg and H. Lomeli for supplying cDNA clones and Drs. D. Coling, J. Fex, R. S. Petralia, and D. Tingley for their comments on this manuscript. Correspondence should be addressed to Dr. Saaid Safieddine, National Institute on Deafness and Other Communication Disorders, National Institutes of Health, Laboratory of Neurochemistry, 36 Convent Drive MSC-4162, Building 36, Room 5D08, Bethesda, MD 20892-4162.

Copyright (C) 1997 Society for Neuroscience $0270-6474 / 97 / 177523-09 \$ 05.00 / 0$
Similar studies have suggested that the vestibular afferent neurotransmitter is an excitatory amino acid (Annoni et al., 1984; Soto and Vega, 1988; Bledsoe et al., 1989).

In the CNS, glutamate mediates most fast excitatory synaptic transmission via activation of three major families of ionotropic receptors. These families are classified by their preferred agonists, NMDA (NR1, NR2A-D), kainate (GluR5-7, KA1, and KA2), and AMPA (GluR1-4) (Hollmann and Heinemann, 1994). A fourth family of glutamate receptors, $\delta$ receptors, has been identified in both rat and mouse brain (Yamazaki et al., 1992; Lomeli et al., 1993). This family consists of two putative subunits, $\delta 1$ and $\delta 2$, that share $56 \%$ amino acid identity (Yamazaki et al., 1992; Lomeli et al., 1993). Although $\delta$ receptors are structurally similar to other glutamate receptors, they have not been demonstrated in vitro to form functional ion channels (Lomeli et al., 1993). The $\delta 2$ receptor is expressed predominantly in Purkinje cells of the cerebellum (Lomeli et al., 1993; Takayama et al., 1995, 1996), whereas $\delta 1$ is relatively abundant in brain at early postnatal stages (Lomeli et al., 1993). The observation that long-term depression at cerebellar glutamatergic synapses is impaired in $\delta 2$ knock-out mice suggests that this subunit plays a crucial role in some forms of plasticity (Kashiwabuchi et al., 1995). In addition, these mice show a deficit in vestibular compensation (Funabiki et al., 1995). These findings and the glutamatergic nature of the vestibulocochlear hair cell nerve synapse imply that the $\delta$ family of glutamate receptors may have an important function in the inner ear. In the present study, we investigated the expression of $\delta$ receptors in the cochlea and vestibular periphery of rat and guinea pig using reverse transcriptase (RT)-PCR, in situ hybridization, and immunocytochemistry. 


\section{MATERIALS AND METHODS}

$R T-P C R$. Primers used to direct PCR amplification of $\delta 1$ and $\delta 2 \mathrm{cDNA}$ were designed on the basis of published nucleotide sequences from the rat (Lomeli et al., 1993) using the DNA-STAR program. Primers for detection of $\delta 1$ transcripts were sense, nucleotides 447-467 (5' CGGGGCCATCCTCCTGCTTAG-3'), and reverse, nucleotides 901880 (5'-GGCCGGTGATGTGTCCCTTTTT-3'). Primers for $\delta 2$ transcripts were sense, nucleotides 2277-2300 (5'-CAATGACCCCGACTGTTCCTTCTA-3'), and reverse, nucleotides 2699-2680 (5'TGGGGGCTGTCGTCATCTGT- $3^{\prime}$ ). All animals used in this study were maintained in accordance with the National Institutes of Health Guide for the Care and Use of Laboratory Animals (National Institutes of Health publication 85-23).

Fifteen rats (Taconic, Germantown, NY) and 15 guinea pigs (National Cancer Institute, Frederick, MD) were anesthetized deeply with carbon dioxide and decapitated. The cochleas were removed from the temporal bones and were microdissected further in cold PBS, pH 7.4. The stria vascularis and the spiral ligament were carefully removed, and the organ of Corti was separated from the spiral ganglion. Finally, the spiral ganglion was microdissected from the modiolus. Both organ of Corti and the spiral ganglion were immediately and rapidly homogenized using a Polytron PT12000 (Brinkmann, Westbury, NY) in the lysis and binding buffer (Dynal, Lake Success, NY) until complete lysis was obtained. mRNA was extracted with oligo-dT-coated magnetic beads (Dynal, Lake Success, NY) according to the manufacturer's instructions. The tota amount of mRNA extracted either from 30 spiral ganglia or from 30 organs of Corti $(<1 \mu \mathrm{g})$ was reverse-transcribed into cDNA. The reaction was catalyzed by Superscript reverse transcriptase (Life Technologies, Gaithersburg, MD) using an oligo-dT primer. The PCR was performed as follows: $94^{\circ} \mathrm{C}$ for $45 \mathrm{sec}, 55^{\circ} \mathrm{C}$ for $1 \mathrm{~min}$, and $72^{\circ} \mathrm{C}$ for $2 \mathrm{~min}(38$ cycles). The last cycle was followed by a $10 \mathrm{~min}$ extension at $72^{\circ} \mathrm{C}$. The PCR products were analyzed by electrophoresis on $1.5 \%$ agarose gels. Cerebellum or hippocampus cDNAs prepared under the same conditions were used as controls. Sequence analysis of the PCR products was performed using a 373A DNA sequencer (Applied Biosystems, Foster City, CA).

In situ hybridization. Male Sprague Dawley rats ( $n=11 ; 150-200 \mathrm{gm})$ and male pigmented guinea pigs $(n=13 ; 200-250 \mathrm{gm})$ were used. They were anesthetized deeply with a 1:1 mixture of ketamine hydrochloride (Ketaset; $100 \mathrm{mg} / \mathrm{ml}$; Fort Dodge Laboratories, Inc.) and xylazine (Rompun; $20 \mathrm{mg} / \mathrm{ml}$; Miles, Elkhart, IN) and perfused through the heart with $10 \mathrm{ml}$ of PBS at room temperature followed by $250 \mathrm{ml}$ of ice-cold $4 \%$ paraformaldehyde in $1 \times \mathrm{PBS}, \mathrm{pH} 7.4$. The cochleas with the peripheral vestibular system attached were further perfused through the round window with the same fixative solution followed by an overnight postfixation and then rinsed for $48-72 \mathrm{hr}$ in phosphate buffer containing $5 \%$ EDTA and $4 \%$ paraformaldehyde. They were then washed overnight in phosphate buffer containing $20 \%$ sucrose and frozen in isopentane at $-60^{\circ} \mathrm{C}$. The cochleas with the peripheral vestibular system attached were cut on a cryostat into $10-\mu \mathrm{m}$-thick sections and stored at $-70^{\circ} \mathrm{C}$ until use. The PCR products corresponding to $\delta 1$ and to $\delta 2$ amplified from the organ of Corti cDNA and cerebellum, respectively, were subcloned into pGEM7Zf $( \pm)$ (Promega, Madison, WI). Nonradioactive in situ hybridization was used to allow better preservation of the organ of Corti and vestibular end organ morphologies and to determine more precisely the expression of mRNA.

Sense and antisense riboprobe in vitro transcription was performed in the presence of digoxigenin (DIG)-UTP according to the manufacturer's suggestions (Genius 4 RNA labeling kit; Boehringer Mannheim, Mannheim, Germany). The size and the purity of the riboprobe made were determined by denaturing agarose gel electrophoresis. The riboprobes were then precipitated with ethanol and $4 \mathrm{M}$ lithium chloride and kept at $-70^{\circ} \mathrm{C}$ for $1 \mathrm{hr}$. The probes were centrifuged at $12,000 \times g$ for $30 \mathrm{~min}$, and the pellet was washed, dried, and then resuspended in diethylpyrocarbonate-treated water. The riboprobe was diluted to 100 $\mathrm{ng} / \mathrm{ml}$ in hybridization buffer.

The in situ hybridization method described in this study is a modification of previously described protocols (Safieddine and Eybalin, 1992b; Safieddine et al., 1996; Niedzielski et al., 1997). Sections were treated with $0.2 \mathrm{M} \mathrm{HCl}$ for $20 \mathrm{~min}$ at room temperature and then washed in $1 \times$ PBS for $10 \mathrm{~min}$. They were incubated in $0.25 \%$ acetic anhydride in $1.5 \%$ triethanolamine, $\mathrm{pH}$, for $10 \mathrm{~min}$ and washed twice for $5 \mathrm{~min}$ each with $1 \times$ PBS. Sections were transferred into prehybridization buffer $[50 \%$ formamide, $250 \mu \mathrm{g} / \mathrm{ml}$ heat-denatured and sheared salmon sperm DNA (Sigma, St. Louis, MO), $100 \mu \mathrm{g} / \mathrm{ml}$ yeast tRNA (Sigma), $4 \times$ SSC $(1 \times$
SSC: 0.15 м sodium chloride, 0.015 м sodium citrate, $\mathrm{pH} 7.2), 1 \times$ Denhart's solution $(0.2 \%$ BSA, $0.2 \%$ polyvinylpyrolidone, $0.2 \%$ Ficoll$400 ; 5 \%$ dextran sulfate)]. Sections were incubated with $100 \mu$ l of the prehybridization buffer containing cRNA at a final concentration of 1 $\mathrm{ng} / \mu \mathrm{l}$ of the labeled riboprobe. The labeled sense riboprobe, at the same concentration, was used as a control. Hybridization was performed overnight at $60^{\circ} \mathrm{C}$. The sections were dipped in $4 \times$ SSC and rinsed in $1 \times$ $\mathrm{SSC}\left(1 \mathrm{hr}\right.$ at room temperature and then $1 \mathrm{hr}$ at $60^{\circ} \mathrm{C}$ ) followed by $0.1 \times$ $\mathrm{SSC}\left(1 \mathrm{hr}\right.$ at $\left.60^{\circ} \mathrm{C}\right)$. Immunological detection of digoxigenin was performed essentially as suggested by the manufacturer. Optimal staining was defined by a series of control experiments in which the reaction was stopped at different time points to maximize staining and to minimize background. Six hours were found to produce optimal staining. A control experiment was performed, either by using labeled sense riboprobe or by omitting the riboprobe in the hybridization buffer.

Western blot analysis and immunocytochemistry. A synthetic peptide (VPGGVLPEALDTSH), corresponding to a sequence near the C terminus of the rat $\delta 1$ subunit (Lomeli et al., 1993), was prepared commercially. The peptide was conjugated to BSA using glutaraldehyde. Antibodies designated anti- $\delta 1$ were made in rabbits and were affinity-purified as described previously (Wenthold et al., 1992).

For Western blot analysis, electrophoresis was performed according to the method of Laemmli (1970) using gels $8 \mathrm{~cm}$ in length with an acrylamide gradient of $4-20 \%$. Proteins were transferred to nitrocellulose membranes as described by Towbin et al. (1979). Membranes were incubated overnight with $5 \%$ nonfat dry milk in Tris-buffered salineTween (TBS-Tween: $50 \mathrm{~mm}$ Tris, $150 \mathrm{~mm} \mathrm{NaCl}$, pH 7.4, containing $0.05 \%$ Tween 20). Antibodies were diluted to $1.5 \mu \mathrm{g} / \mathrm{ml}$, and bound antibody was detected using either alkaline phosphatase (Kirkegaard \& Perry, Gaithersburg, MD) or chemiluminescence (New England Nuclear, Boston, MA). Prestained molecular weight standards from Life Technologies were myosin, phosphorylase $b$, BSA, ovalbumin, carbonic anhydrase, $\beta$-lactoglobulin, and lysozyme, migrating at values of $M_{\mathrm{r}} 203,000$, $105,000,71,000,44,600,28,000,18,000$, and 15,000 , respectively.

For immunocytochemistry, the fixation procedure and tissue preparation were the same as described above for in situ hybridization. The immunocytochemical procedure was similar to that described previously (Safieddine and Eybalin, 1992a). Briefly, the tissue sections were rinsed three times for 20 min each in PBS containing 0.2\% BSA and then were preincubated for $1 \mathrm{hr}$ in PBS-BSA with $30 \%$ normal goat serum. Preincubation buffer was removed, and the primary antibodies to $\delta 1$ and $\delta 1 / 2$ were diluted to $1.5 \mu \mathrm{g} / \mathrm{ml}$ and applied to the sections, either alone or in combination with an anti-synaptophysin monoclonal antibody (Boehringer Mannheim) that has been shown to label the cochlear efferent presynaptic terminals (Gil-Loyzaga and Pujol, 1988). After $24 \mathrm{hr}$ of incubation at $4^{\circ} \mathrm{C}$, the sections were rinsed in PBS-BSA (three times for $20 \mathrm{~min}$ each), incubated for $2 \mathrm{hr}$ with secondary anti-rabbit IgG antibody raised in goat (Boehringer Mannheim), and conjugated to dichlorotriazinyl aminofluorescein (DTAF). For the double labeling, the sections were incubated with a mixture of an anti-mouse IgG raised in goat and conjugated to rhodamine and the anti-rabbit IgG conjugated to DTAF. The sections were then rinsed in PBS (three times for $20 \mathrm{~min}$ each) and mounted in FluorSave medium (Calbiochem, San Diego, CA).

\section{RESULTS \\ RT-PCR analysis}

Organs of Corti and spiral ganglia were screened for $\delta$ receptor expression using RT-PCR. The organ of Corti, which contains hair cells and supporting cells, can be dissected free of SGNs and other inner ear structures. The results showed the expression of $\delta 1$ in both organ of Corti and spiral ganglion, whereas $\delta 2$ was expressed in neither (Fig. 1A,B). Similar results were obtained using both rats and guinea pigs, and except where noteworthy, we describe our results irrespective of species used. To verify the integrity of the mRNA extracted from the organ of Corti, we used the nicotinic receptor subunit $\alpha 9$, which is expressed in hair cells (Elgoyhen et al., 1994), as a control. Using the $\delta 1$ primers, we observed a cDNA in the hippocampus, a tissue known to express $\delta 1$ (Lomeli et al., 1993), similar in size to that obtained in the organ of Corti and spiral ganglion (Fig. $1 A$ ). For the $\delta 2$ primers (Fig. $1 B$ ), a cDNA of the predicted size was present in the 

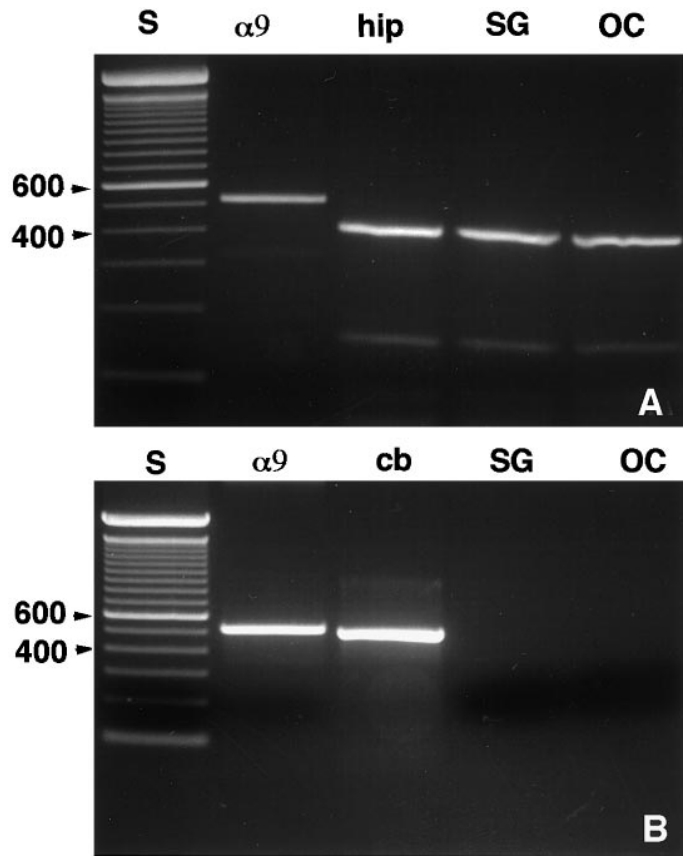

Figure 1. Agarose gel electrophoresis of PCR products amplified from rat brain, organ of Corti, and spiral ganglion with specific primers for $\delta 1$ $(A)$ or $\delta 2(B)$. Lane $S, 100$ bp standard; lane $\alpha 9, \alpha 9$ nicotinic receptor from organ of Corti cDNA; lane $O C$, organ of Corti; lane $S G$, spiral ganglion; lane hip, hippocampus; and lane $c b$, cerebellum. The bands are labeled in units of $100 \mathrm{bp}$ (100 bp DNA ladder standard; Life Technologies).

cerebellum, a tissue in which $\delta 2$ is highly expressed (Takayama et al., 1996). Sequence analysis of the full-length PCR products from both rat and guinea pig organ of Corti and spiral ganglion and the search in the data bank showed over $95 \%$ sequence homology to both rat and mouse $\delta 1$ receptors at the nucleotide level. Furthermore, the amplification and the sequence analysis of the C-terminal region (2467-2753 bp) of the guinea pig $\delta 1$ gene also showed a $95 \%$ homology to both mouse and rat sequences. Sequence analysis of the PCR product corresponding to $\delta 2$ amplified from guinea pig cerebellum gave a similar degree of homology.

\section{In situ hybridization}

In situ hybridization with $\delta 1$ - and $\delta 2$-specific riboprobes showed that $\delta 2$ is not expressed in cochlear hair cells or SGNs (Fig. $2 A$ ), whereas $\delta 1$ expression in the organ of Corti is restricted to the IHCs (Fig. 2B). No turn-dependent variation in expression was seen. In the spiral ganglion, $\delta 1$ glutamate receptor mRNA was expressed in SGNs (Fig. $2 C, D$ ) with prominent expression in the large type I neurons. Smaller neurons, with a tendency to be found at the periphery of the ganglion, also expressed $\delta 1$ glutamate receptor transcripts at high levels (Fig. 2C,D). Based on the size, number, and location of these small neurons, we assume that they represent the type II SGNs. $\delta 1$ expression in the spiral ganglion showed a homogenous and similar pattern along the entire cochlear spiral (Fig. 2C). The greater histological resolution of the nonradioactive in situ hybridization enabled us to see, in several cases, that the satellite glial cells that surround the SGNs also were stained (Fig. 2C,D). The labeled sense strand riboprobe failed to show any positive staining in a complete series of sections from the same cochlea that displayed a positive signal with antisense probes (data not shown). Analysis of sections containing vestibular hair cells and the vestibular ganglion, hybridized with $\delta 1$ or with $\delta 2$ riboprobe, showed that $\delta 1$ mRNA is also highly expressed in both VHCI and VHCII and in supporting cells (Fig. $3 B$ ) as well as in vestibular ganglion neurons (Fig. 3C). None of these cells was found expressing $\delta 2$ mRNA (Fig. $3 A$ ).

\section{Western blot analysis}

To determine whether $\delta 1$ protein is expressed in the inner ear, we made a specific antibody to the $\delta 1$ receptor. Previous studies (Wenthold et al., 1990, 1992; Petralia and Wenthold, 1992; Petralia et al., 1994; Mayat et al., 1995) showed that the C-terminal region of other members of the glutamate receptor family was useful for producing specific antibodies that could be used in Western blots and immunocytochemistry. We thus chose the region near the $\mathrm{C}$ terminal of $\delta 1$ to make a $\delta 1$ antibody. To eliminate a possible cross-reaction with $\delta 2$, we did not use the last four amino acids of the $\mathrm{C}$ terminal of $\delta 1$ that are identical to those of $\delta 2$ in making the $\delta 1$-specific antibody. Western blot analysis of membranes from cells transfected with $\delta 1$ or $\delta 2$ cDNA showed that the antibody recognizes only $\delta 1$ subunits (Fig. $4 A$ ). Both organ of Corti and cochlear spiral ganglia of rat and guinea pig show a major immunoreactive band at $115 \mathrm{kDa}$ that comigrates with the $\delta 1$ band from transfected cells (Fig. $4 B$ ). The same bands were detected using $\delta 1 / 2$ antibody (Fig. $4 C$ ) that has been reported to recognize both $\delta 1$ and $\delta 2$ receptors (Mayat et al., 1995).

\section{Immunocytochemistry}

In the organ of Corti, the immunoreactivity to both $\delta 1$ and $\delta 1 / 2$ antibodies was intense and restricted to the IHCs (Fig. $5 A, B$, also see Fig. $7 A$ ). No immunostaining was seen in OHCs, Deiters cells, Hensen cells, or the stria vascularis. The tectorial membrane, which very often shows a nonspecific staining (Altschuler et al., 1985; Abou-Madi et al., 1987; Safieddine and Eybalin, 1992a), was devoid of $\delta 1$ immunoreactivity (Fig. $5 A, B$ ). The base, middle, and apical organ of Corti displayed the same pattern of immunostaining. Occasionally a moderate immunostaining to $\delta 1$ was seen in Claudius cells (Fig. 5B). This is consistent with the light-tomoderate in situ hybridization signal observed in Claudius cells (Fig. 2B). In the spiral ganglion, all the SGNs were immunostained with the $\delta 1$ and $\delta 1 / 2$ antibodies with no apparent turndependent pattern of expression. The intensity of the immunostaining was moderate to high (Fig. 6A,B). As seen with in situ hybridization, apparent type II neurons as well as satellite glial cells were immunoreactive.

From the immunocytochemistry results shown in Figure 5, it is difficult to determine whether $\delta 1$ expression is restricted to IHCs or whether efferent terminals and fibers beneath IHCs are also immunoreactive. To address this question, we performed a double-labeling experiment using $\delta 1$ antibody together with a monoclonal synaptophysin antibody that has been shown to be a specific marker for the cochlear efferent nerve terminals (GilLoyzaga and Pujol, 1988). Synaptophysin immunoreactivity was present in the inner spiral bundle (ISB), beneath the IHC, and in the outer spiral bundle (OSB) that is located beneath the OHCs (Fig. 7B). Neither type of hair cell was immunostained (Fig. 7B). The structures immunoreactive to synaptophysin in the ISB did not contain $\delta 1$ immunoreactivity (Fig. $7 A, B$ ), indicating that $\delta 1$ is not expressed in the efferent innervation to the cochlea.

In the vestibular end organ, both VHCI and VHCII displayed intense immunoreactivity to both $\delta 1 / 2$ and $\delta 1$ antibodies (Fig. $8 A)$. A light immunostaining was also seen in supporting cells (Fig. $8 A$ ), and consistent with in situ hybridization results, most of the vestibular ganglion neurons were immunoreactive (Fig. 8B). 

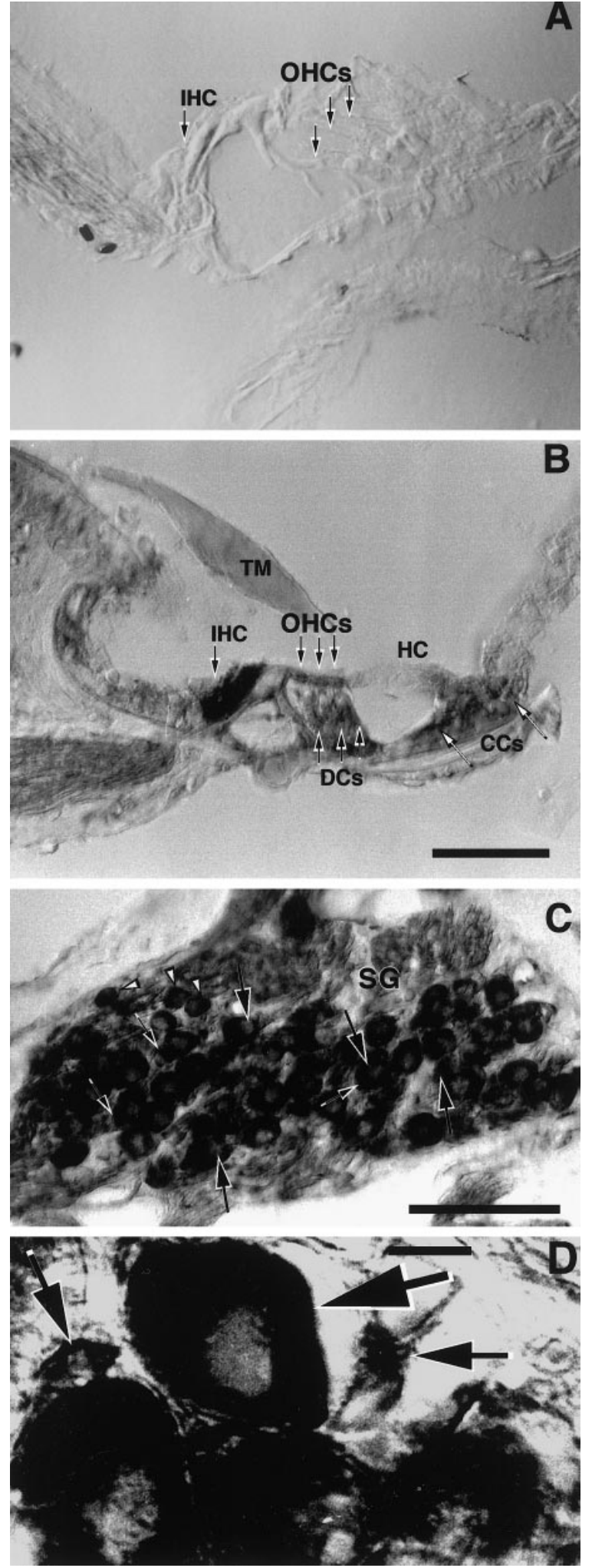

Figure 2. Sections through the organ of Corti $(A, B)$ and the spiral ganglion $(S G)(C, D)$ of the rat. $A$, Section hybridized with DIG-labeled $\delta 2$ antisense riboprobe showing no specific staining. $B, C, D$, Sections hybridized with DIG-labeled $\delta 1$ antisense riboprobe. In $B$ (basal turn), the $I H C s$ display an intense hybridization signal. No hybridization signal is seen in the $\mathrm{OHCs}$, Deiters cells $(D C s)$, Claudius cells $(C C s)$, or the tectorial membrane (TM). In $C$ (second turn) and $D$ (apical turn), type I (large arrows) and putative type II (arrowheads) neurons and satellite glial cells (small arrows) express the $\delta 1$ mRNA at high levels. Scale bars: $A, B, 50 \mu \mathrm{m} ; C, 100 \mu \mathrm{m} ; D, 10 \mu \mathrm{m}$.
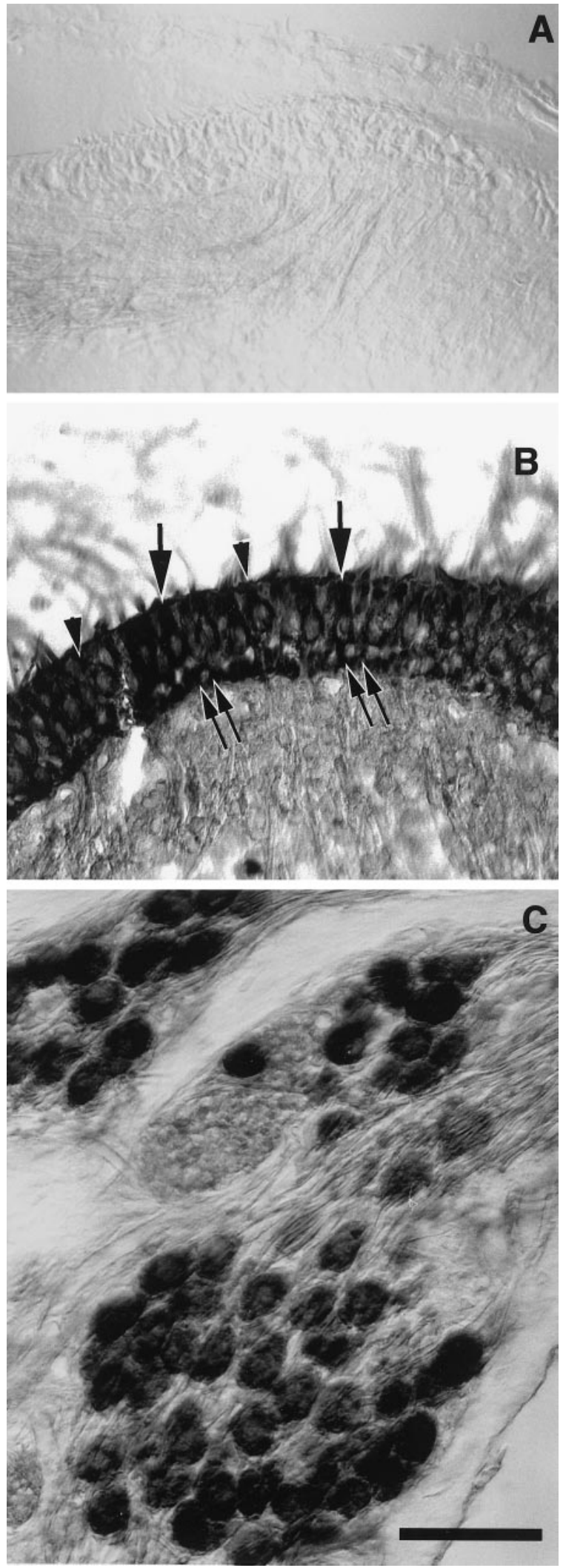

Figure 3. Sections through the crista ampullaris $(A, B)$ of the rat and the vestibular ganglion of the guinea pig $(C)$. $A$, Section hybridized with DIGlabeled $\delta 2$ antisense riboprobe. Only background is observed. $B, C$, Sections hybridized with DIG-labeled $\delta 1$ antisense riboprobe. In $B$, type I (arrowheads) and type II (arrows) vestibular hair cells showed an intense hybridization signal. In $C$, most of the ganglion neurons are intensely labeled. Scale bar, $50 \mu \mathrm{m}$. 


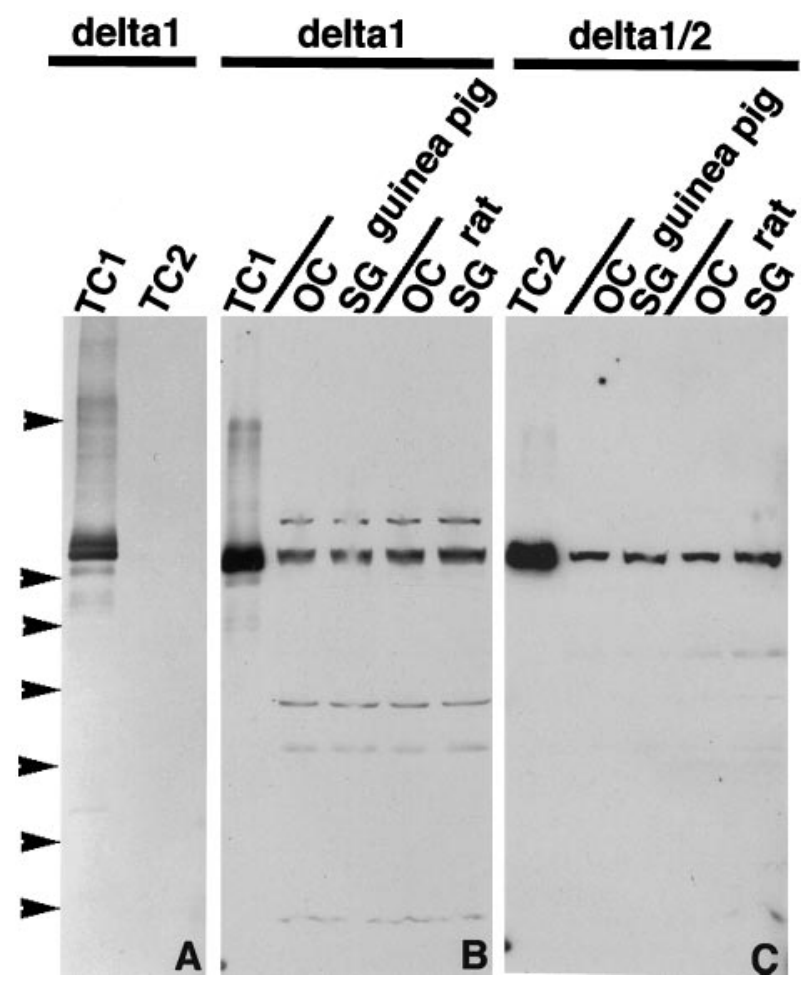

Figure 4. SDS-PAGE and immunoblot analysis of $\delta 1$ (TC1)- and $\delta 2$ (TC2)-transfected cell membranes, organ of Corti $(O C)$, and spiral ganglion $(S G)$ using anti- $\delta 1(A, B)$ and anti- $\delta 1 / 2(C)$ antibodies. With both antibodies $(B, C)$, a major immunoreactive band, which comigrates with the $\delta 1$-immunoreactive band, is seen in $O C$ and $S G$ in both rat and guinea pig as well as in membranes of cells transfected with $\delta 1$ cDNA. Arrowheads show the positions of prestained standards (from top to bottom): myosin $\left(M_{\mathrm{r}}=203,000\right)$, phosphorylase $b\left(M_{\mathrm{r}}=105,000\right)$, BSA $\left(M_{\mathrm{r}}=\right.$ $71,000)$, ovalbumin $\left(M_{\mathrm{r}}=44,600\right)$, carbonic anhydrase $\left(M_{\mathrm{r}}=28,000\right)$, $\beta$-lactoglobulin $\left(M_{\mathrm{r}}=18,000\right)$, and lysozyme $\left(M_{\mathrm{r}}=15,000\right)$.

\section{DISCUSSION}

Using RT-PCR, in situ hybridization, and immunocytochemistry, we have provided compelling evidence that the $\delta 1$ glutamate receptor subunit is expressed in the inner ear. In the organ of Corti, $\delta 1$ expression was restricted to IHCs, whereas in the spiral ganglia, $\delta 1$ was detected in SGNs as well as in their satellite glial cells. In the vestibular end organ, $\delta 1$ expression was seen in both VHCI and VHCII as well as in the vestibular ganglion cells. However, $\delta 2$ was detected in neither, suggesting that the vestibular deficit compensation observed in $\delta 2$ knock-out mice (Funabiki et al., 1995) may be caused by the absence of $\delta 2$ expression in the brainstem and/or cerebellum. Neither $\delta 1$ nor $\delta 2$ forms functional ion channels when expressed in oocytes or transfected cells, and they do not seem to combine with other glutamate receptors (Yamazaki et al., 1992; Lomeli et al., 1993). A possible explanation for this lack of function is that additional subunits, yet to be identified, are required for a complete receptor complex. The evidence that $\delta 1$ and $\delta 2$ are glutamate receptors is based on their structural similarities to ionotropic glutamate receptors. The selective and relatively robust expression of $\delta 1$ in IHCs and vestibular hair cells raises interesting questions about its functional role in these cells. Assuming that $\delta$ receptors form functional ion channels, there are two likely roles for $\delta 1$ receptors in these cells. First, they may function as autoreceptors. Several lines of evidence indicate that the neurotransmitter of the inner ear hair cells is an excitatory amino acid (Bledsoe et al., 1981,
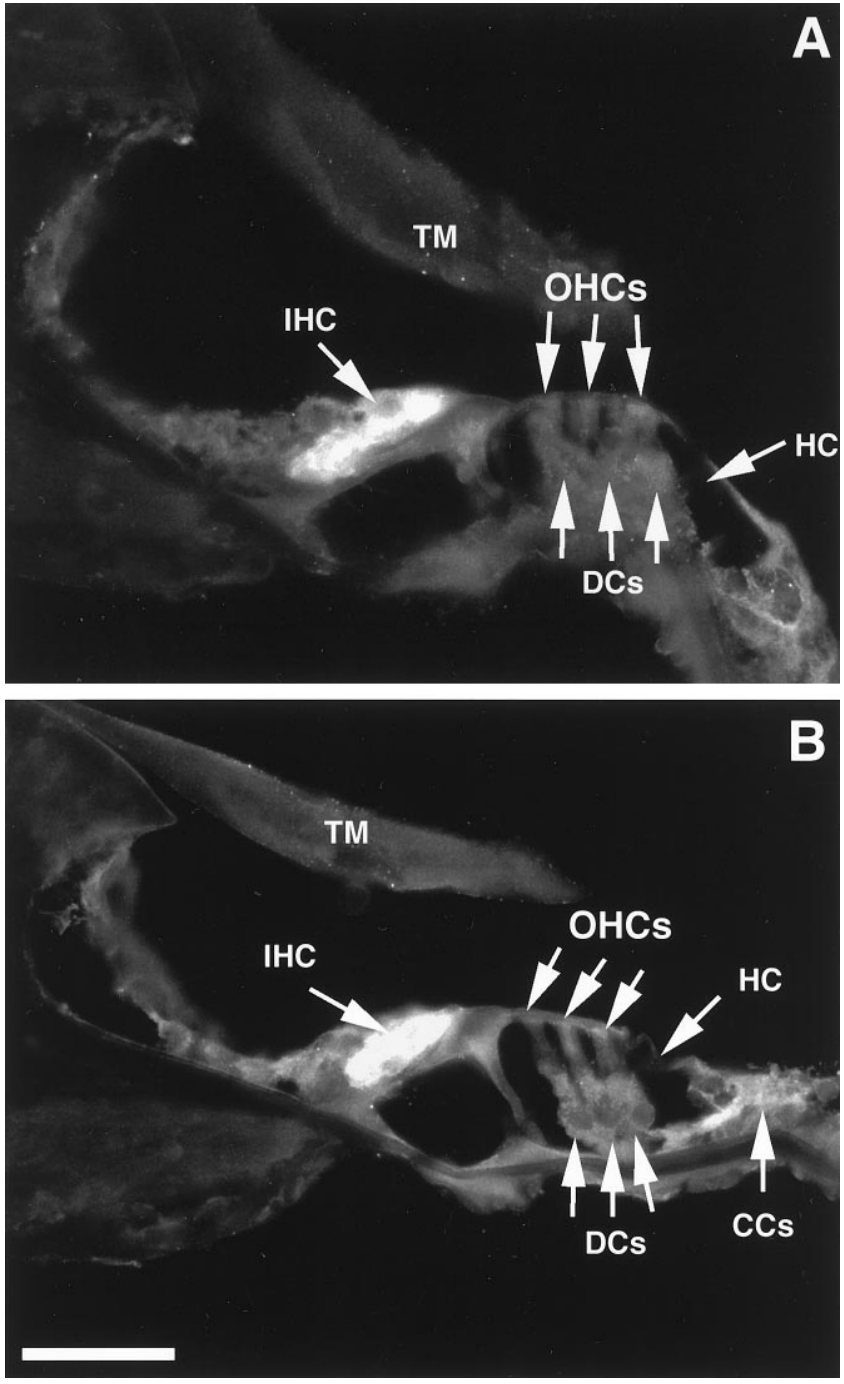

Figure 5. Sections through the second turn $(A)$ and through the third turn $(B)$ of the organ of Corti of the guinea pig incubated at $1.5 \mu \mathrm{g} / \mathrm{ml}$ with anti- $\delta 1 / 2$ and $-\delta 1$ antibodies, respectively. The immunoreactivity was visualized with a fluorescein-labeled secondary antibody. The $I H C$ shows an intense immunostaining to both $\delta 1$ and $\delta 1 / 2$ antibodies. The $O H C s$, Hensen cells $(H C s)$, Deiters cells $(D C s)$, and tectorial membrane (TM) are not immunoreactive. Immunostaining to $\delta 1$ is occasionally seen in the Claudius cells $(C C s)$. Scale bar, $100 \mu \mathrm{m}$.

1989; Annoni et al., 1984; Soto and Vega, 1988; Puel et al., 1991a,b, 1994; Kataoka and Ohmori, 1994), and $\delta 1$ may regulate its release from the hair cell. Restriction of $\delta 1$ expression to IHCs in the organ of Corti is consistent with the fact that most (9095\%) afferent transmission is from IHCs (Spoendlin, 1972; Berglund and Ryugo, 1987); OHCs may not need to regulate their excitatory amino acid release, which may occur only at modest levels, because OHCs form synapses on the remaining 5\% of type II SGNs. An argument against the autoreceptor idea is the fact that studies in the CNS, using an antibody that detects both $\delta 1$ and $\delta 2$, show that immunoreactivity is primarily postsynaptic with little or no presynaptic staining (Mayat et al., 1995; Petralia et al., 1996; Landsend et al., 1997; Petralia, 1997; Zhao et al., 1997). Therefore, the role of $\delta 1$ as an autoreceptor would be limited to the inner ear. A second possible role for $\delta 1$ in IHCs could be as an efferent receptor. Based mostly on high-affinity uptake results (Gulley et al., 1979; Eybalin and Pujol, 1983; Ryan 

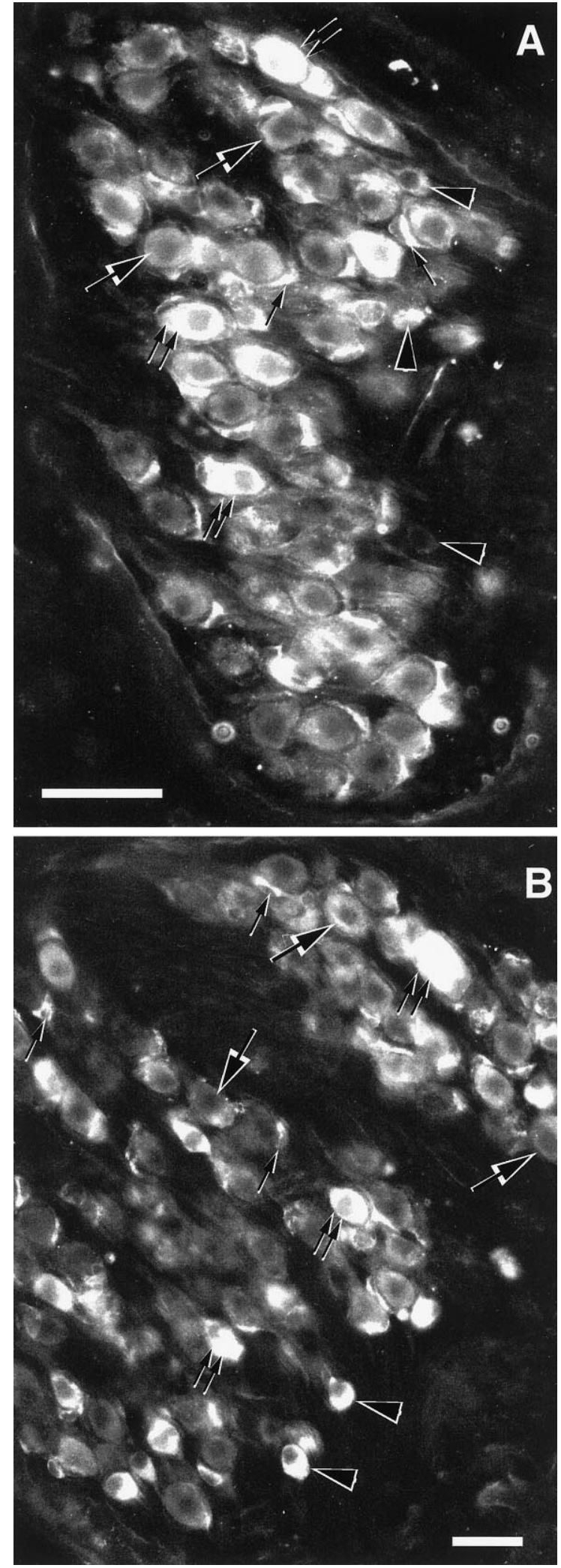

Figure 6. Sections through the basal turn $(A)$ and through the apical turn $(B)$ of the rat spiral ganglion incubated at $1.5 \mu \mathrm{g} / \mathrm{ml}$ with anti- $\delta 1$ and $-\delta 1 / 2$ antibodies, respectively. All type I (large and double arrows) and type II (arrowheads) spiral ganglion neurons show staining to both $\delta 1$ and $\delta 1 / 2$ antibodies. The intensity of the immunostaining is moderate (large arrows) to intense (double arrows). Satellite glial cells show intense immunostaining to $\delta 1$ and $\delta 1 / 2$ antibodies (small single arrows). Scale bars: $A, B, 50 \mu \mathrm{m}$.
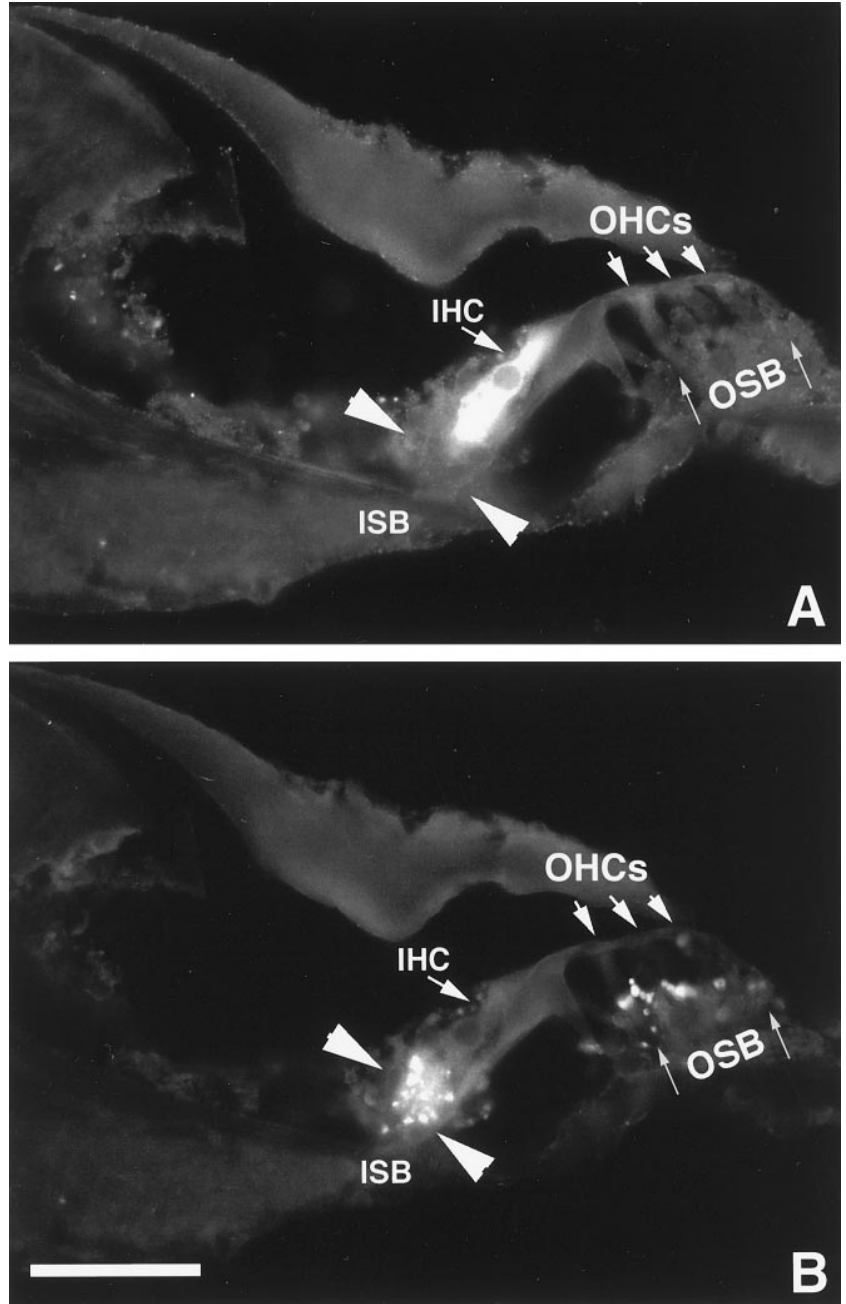

Figure 7. Colocalization of the immunoreactivity to $\delta 1(A)$ and synaptophysin $(B)$ antigens in the organ of Corti of the guinea pig. $A$, Field illuminated for DTAF fluorescence. $B$, Field illuminated for rhodamine. The $I H C$ is immunoreactive to the $\delta 1$ antibody only, and no immunostaining is seen in the $O H C$ region $(A)$. The $I S B$, delineated by two arrowheads, and the $O S B$, indicated by thin arrows, are stained with antibody to synaptophysin antibody $(B)$ but not with $\delta 1$ antibody $(A)$. Scale bar, $50 \mu \mathrm{m}$.

et al., 1987), proposals have been made that efferents use an excitatory amino acid neurotransmitter, in addition to other identified transmitters that include acetylcholine, GABA, enkephalin, dynorphin, dopamine, and calcitonin gene-related peptide (for review, see Eybalin, 1993; Puel, 1995). IHCs of adult animals generally are not thought to receive efferent innervation, although there have been reports of efferent fibers near IHCs with some reports of synaptic contact (Liberman et al., 1990; Sobkowicz and Slapnick, 1994). In addition, efferent terminals make transient synaptic contact on IHCs during development (Pujol et al., 1978; Lenoir et al., 1980; Shnerson et al., 1982; LavigneRebillard and Pujol, 1988; Hashimoto et al., 1990; Simmons et al., $1991,1996)$, and $\delta 1$ expression in adult animals may be a vestige of this contact. The $\alpha 9$ subunit of the nicotinic receptor, the major mediator of cholinergic efferent activity, and the muscarinic receptor $\mathrm{m} 3$ are also expressed in adult IHCs (Elgoyhen et al., 1994; Safieddine et al., 1996), and a similar role for those receptors has been proposed. In contrast to the organ of Corti, there are no data favoring an excitatory amino acid as a vestibular 

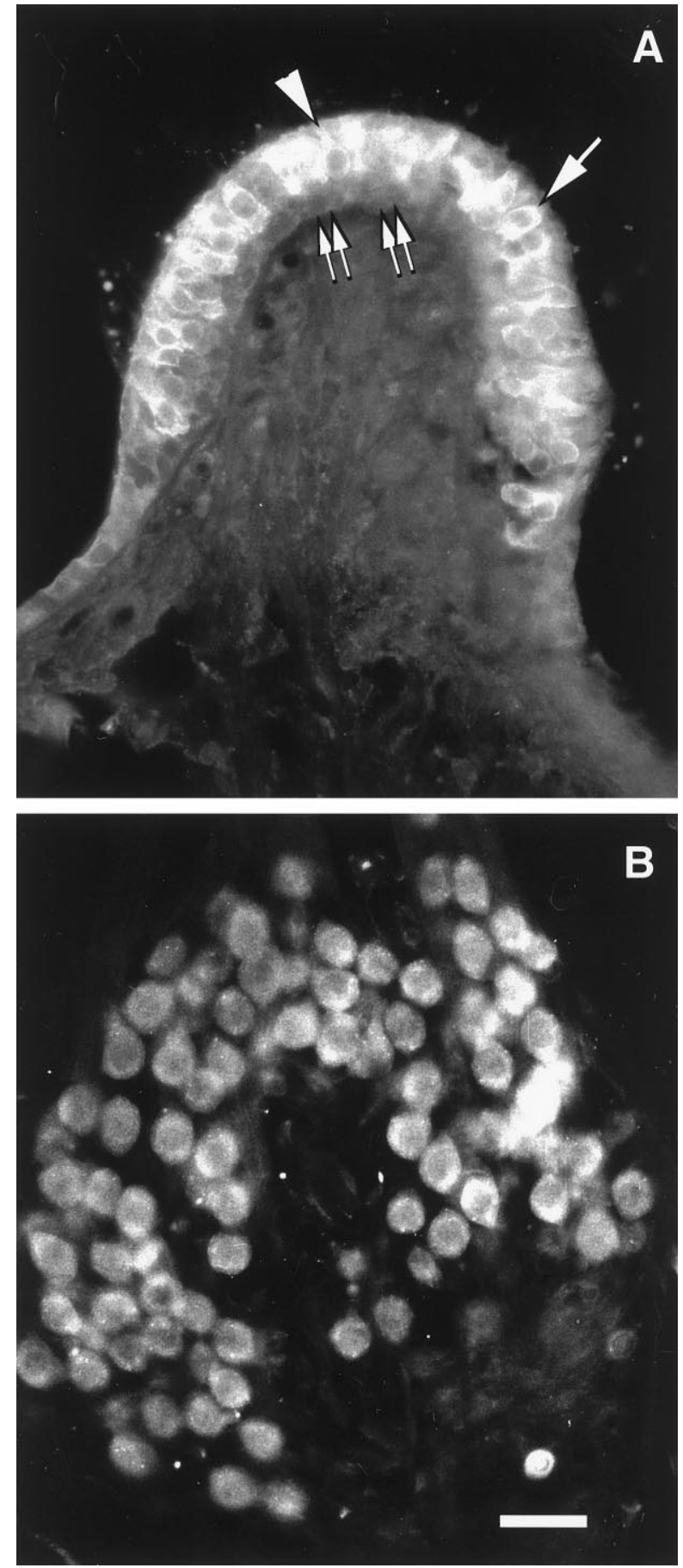

Figure 8. Sections through the crista ampullaris $(A)$ and the vestibular ganglion $(B)$ of the rat. The sections have been incubated with $\delta 1 / 2$ antibody at $1.5 \mathrm{mg}$. In $A$, both type I (arrowhead) and type II (arrow) hair cells are immunoreactive to the $\delta 1 / 2$ antibody. Supporting cells (double arrows) display a weak immunostaining. In $B$, most of the vestibular ganglion cells are immunoreactive. Scale bar, $50 \mu \mathrm{m}$.

efferent neurotransmitter. However, previous reports showed that the calyx surrounding type I hair cells contains several proteins involved in neurotransmitter release (Scarphone et al., 1988) and that type I cells respond to glutamate agonists (Devau et al., 1993). These findings suggest that, at least in type I hair cells, $\delta 1$ could be activated by a putative excitatory amino acid either released by the calyx or present in the perilymph. Such a neuro- transmitter could also activate $\delta 1$ on supporting cells that are also in contact with the perilymph. An argument against the role of $\delta 1$ as an autoreceptor or an efferent receptor is that $\delta 1$ immunoreactivity does not appear to be concentrated near the base of the hair cell, where the synaptic contacts are made. But the distribution of $\delta 1$ throughout the hair cells may reflect a relatively large intracellular receptor pool, which seems to be a characteristic of glutamate receptors in neurons (Hampson et al., 1992; Petralia and Wenthold, 1992; Petralia, 1997). At the ultrastructural level, glutamate receptors are shown to be concentrated at the synapse (Mayat et al., 1995; Petralia et al., 1996; Petralia, 1997), and such studies may show a similar concentration of $\delta 1$ at the base of the hair cells. Although its role as an autoreceptor or efferent receptor seems the most likely, we cannot rule out the possibility of a novel role for $\delta 1$ in hair cells. For example, they are in contact with perilymph, and $\delta 1$ could be involved in detecting excitatory amino acids, or other substances, in perilymph. The role of $\delta 1$ in the inner ear may become clear when the function of $\delta 1$ is established.

Several other neurotransmitter receptors have been reported to be expressed in both vestibular and cochlear hair cells, including AMPA receptors (Devau et al., 1993; Kuriyama et al., 1994; Demêmes et al., 1995; Matsubara et al., 1996; Knipper et al., 1997), the muscarinic receptor $m 3$ (Safieddine et al., 1996), and $\alpha 9$ nicotinic receptors (Elgoyhen et al., 1994). None of these receptors is found solely expressed in IHCs of the organ of Corti. Collectively, these findings tend to suggest that hair cell neurotransmission is more complex than originally envisioned and may involve multiple neurotransmitters and receptors. The present results also suggest that $\delta 1$ is present in Claudius cells. One possible hypothesis is that Claudius cells, like Hensen cells, are in contact with the cochlear perilymph, and thus any receptors expressed in those cells, including $\delta 1$, may be exposed to excitatory amino acids present in the perilymph.

Both large and small SGNs as well as vestibular ganglion cells express $\delta 1$. The small SGNs are found around the periphery of the ganglia, characteristic of type II neurons. These results suggest that both SGNs and vestibular ganglion cells express $\delta 1$. The variation in the immunostaining observed among neurons may reflect functional differences. However, the uniformity of the in situ hybridization signal obtained argues against this, and we believe that this variability may be because of technical causes such as antibody penetration. Previous studies demonstrated that presynaptic terminals of the auditory nerve in the cochlear nucleus do not display any immunoreactivity to $\delta 1 / 2$ antibodies (Petralia et al., 1996), implying that $\delta 1$ subunit expression is restricted to the dendrites of SGNs. The functional site could be either postsynaptic to the hair cell or postsynaptic to the lateral efferent input to spiral ganglion cell dendrites beneath IHCs. The presence of $\delta 1$ postsynaptic to hair cells is consistent with the hypothesis that an excitatory amino acid is the neurotransmitter of hair cells (Annoni et al., 1984; Soto and Vega, 1988; Bledsoe et al., 1989; for review, see Eybalin, 1993; Puel, 1995). Spiral and vestibular ganglion neurons express many glutamate receptors including AMPA, kainate, and NMDA ionotropic receptors and several metabotropic receptors (Ryan et al., 1991; Safieddine and Eybalin, 1992b, 1995; Demêmes et al., 1995; Niedzielski and Wenthold, 1995; Usami and Ottersen, 1995). Although only AMPA receptors have been shown to be postsynaptic to hair cells (Kuriyama et al., 1994; Demêmes et al., 1995; Usami and Ottersen, 1995; Matsubara et al., 1996), it is generally assumed that all of these receptors are expressed on the postsynaptic mem- 
brane of afferent fibers. AMPA and kainate receptors have been characterized pharmacologically (Billett et al., 1989; Nakagawa et al., 1991; Puel et al., 1991b, 1994; Pujol et al., 1992; Deveaux et al., 1993), and some studies have identified functional NMDA receptors on SGNs (Felix and Ehrenberger, 1990; Puel et al., 1991a,b; Pujol et al., 1992). Intracochlear coperfusion of AMPA and NMDA antagonists failed to abolish the cochlear action potential (Puel et al., 1991b), suggesting that additional receptors, such as $\delta$ and metabotropic receptors, may be involved in transmission at the hair cell synapse.

The $\delta 1$ subunit is also expressed in satellite glial cells in the spiral ganglion. This is in agreement with other studies describing expression of several glutamate receptors, including the $\delta$ family, by glial cells in the cochlea and in the CNS (Safieddine and Eybalin, 1992b; Mayat et al., 1995; Niedzielski and Wenthold, 1995; Petralia et al., 1996). It has been proposed that the activation of these receptors can regulate glial cell metabolism and neuron-glial interactions (Jonathan and Abbot, 1996; Steinhauser and Gallo, 1996).

In conclusion, the present results show that $\delta 1$ is prominently expressed in IHCs and in type I and type II vestibular cells, suggesting a functional role in hair cell neurotransmission. Excitotoxic damage to ganglion cell dendrites from excessive stimulation has been reported and proposed as a mechanism for noiseinduced damage to the cochlea (Billett et al., 1989; Pujol et al., 1992; Puel et al., 1994). If this is proven to be the case, glutamate receptors, including $\delta$, on hair cells may play a role in hair cell degeneration under conditions of overstimulation.

\section{REFERENCES}

Abou-Madi L, Pontarotti P, Tramu G, Cupo A, Eybalin M (1987) Coexistence of putative neuroactive substances in lateral olivocochlear neurons in guinea pig and rat. Hear Res 30:135-146.

Altschuler RA, Kachar B, Rubio JA, Parakkal MA, Fex J (1985) Immunocytochemical localization of choline acetyltransferase-like immunoreactivity in the guinea pig cochlea. Brain Res 338:1-11.

Annoni JM, Cochran SL, Precht W (1984) Pharmacology of the vestibular hair cells afferent fiber synapses in the frog. J Neurosci 4:2106-2116.

Berglund A-M, Ryugo DK (1987) Hair cell innervation by spiral ganglion neurons in the mouse. J Comp Neurol 255:560-570.

Billett TE, Thorne P, Gavin JB (1989) The nature and progression of injury in the organ of Corti during ischemia. Hear Res 41:189-198.

Bledsoe SC, Bobbin RP, Chihal DM (1981) Kainic acid: an evaluation of its action on cochlear potentials. Hear Res 4:109-120.

Bledsoe SC, Mc Laren JD, Meyer JR (1989) Potassium induced release of endogenous glutamate and two as yet unidentified substances from lateral line of Xenopus laevis. Brain Res 493:113-122.

Bobbin RP, Ceasar G, Fallon M (1990) Potassium induced release of GABA and other substances from guinea pig cochlea. Hear Res 46:83-94.

Bobbin RP, Ceasar G, Fallon M (1991) Changing cation levels $\left(\mathrm{Mg}^{2+}\right.$, $\mathrm{Ca}^{2+}, \mathrm{Na}^{+}$) alters the release of glutamate, GABA and other substances from guinea pig cochlea. Hear Res 54:135-144.

Demêmes D, Lleixa A, Dechesne CJ (1995) Cellular and subcellular localization of AMPA-selective glutamate receptors in the mammalian peripheral vestibular system. Brain Res 671:83-94.

Devau G, Lehoulleur J, Sans A (1993) Glutamate receptors on type I hair cells of guinea pig. Eur J Neurosci 5:1210-1217.

Elgoyhen AB, Johnson DS, Boulter J, Vetter DW, Heinemann S (1994) $\alpha 9$ : an acetylcholine receptor with novel pharmacological properties expressed in rat cochlear hair cells. Cell 79:705-715.

Eybalin M (1993) Neurotransmitters and neuromodulators of the mammalian cochlea. Physiol Rev 73:309-373.

Eybalin M, Pujol R (1983) A radioautographic study of [ $\left.{ }^{3} \mathrm{H}\right]$ L-glutamate and $\left[{ }^{3} \mathrm{H}\right]$ L-glutamine uptake in the guinea pig cochlea. Neuroscience 9:863-871.

Felix D, Ehrenberger K (1990) A microiontophoretic study of the role of excitatory amino acids at the afferent synapses of mammalian inner hair cells. Eur Arch Otorhinolaryngol 248:1-3.

Funabiki K, Mishina M, Hirano T (1995) Retarded vestibular compensation in mutant mice deficient in $\delta 2$ glutamate receptor subunit. NeuroReport 7:189-192.

Gil-Loyzaga P, Pujol R (1988) Synaptophysin in developing cochlea. Int J Dev Neurosci 6:155-160.

Gulley RL, Fex J, Wenthold RJ (1979) Uptake of putative transmitter in the organ of Corti. Acta Otolaryngol 88:177-182.

Hampson DR, Huang XP, Oberdorfer MD, Goh JW, Auyeung A, Wenthold RJ (1992) Localization of AMPA receptors in the hippocampus and cerebellum of the rat using an anti-receptor MAb. Neuroscience 50:11-22.

Hashimoto S, Kimura RS, Takasaka T (1990) Computer-aided threedimensional reconstruction of the inner hair cells and their nerve endings in the guinea pig cochlea. Acta Otolaryngol 109:228-234.

Hollmann M, Heinemann S (1994) Cloned glutamate receptors. Annu Rev Neurosci 17:31-108.

Jenisson GL, Bobbin RP, Thalmann R (1985) Potassium-induced release of endogenous amino acids in the guinea pig cochlea. J Neurochem 44:1845-1853.

Jonathan AC, Abbot J (1996) Signaling from neurons to glial cells in invertebrates. Trends Neurosci 19:358-362.

Kashiwabuchi N, Ikeda K, Araki K, Hirano T, Shibuki K, Takayama C, Inoue Y, Kutsuwada T, Yagi T, Kang Y, Aizawa S, Mishina M (1995) Impairment of motor coordination, Purkinje cell synapse formation, and cerebellar long-term depression in GluR $\delta 2$ mutant mice. Cell 81:245-252.

Kataoka Y, Ohmori H (1994) Activation of glutamate receptors in response to membrane depolarization of hair cells isolated from chick cochlea. J Physiol (Lond) 477:403-414.

Knipper M, Köpschall I, Rohbock K, Köpke AKE, Bonk I, Zimmermann U, Zenner H-P (1997) Transient expression of NMDA receptors during rearrangement of AMPA-receptor-expressing fibers in the developing inner ear. Cell Tissue Res 287:23-41.

Kuriyama H, Jenkins O, Altschuler RA (1994) Immunocytochemical localization of AMPA selective glutamate receptor subunits in rat cochlea. Hear Res 80:233-240.

Laemmli UK (1970) Cleavage of structural proteins during the assembly of the head bacteriophage T4. Nature 227:680-685.

Landsend A, Amiry-Moghaddam S, Matsubara A, Bergersen L, Usami S-I, Wenthold RJ, Ottersen OP (1997) Differential localization of $\delta$ glutamate receptor in the rat cerebellum, coexpression with AMPA receptors in parallel fiber-spine synapses and absence from climbing fiber-spine synapses. J Neurosci 17:834-842.

Lavigne-Rebillard M, Pujol R (1988) Hair cell innervation in fetal human cochlea. Acta Otolaryngol 105:398-402.

Lenoir M, Shnerson A, Pujol R (1980) Cochlear receptor development in the rat with emphasis on synaptogenesis. Anat Embryol (Berl) 160:253-262.

Liberman MC, Dodds LW, Pierce S (1990) Afferent and efferent innervation of cat cochlea: quantitative analysis with light and electron microscopy. J Comp Neurol 301:443-460.

Lomeli H, Sprengel R, Laurie DJ, Köhr G, Herb A, Seeburg PH, Wisden W (1993) The rat delta-1 and delta-2 subunits extend the excitatory amino acid receptor family. FEBS Lett 315:318-322.

Matsubara A, Laake JH, Davanger S, Usami S-I, Ottersen OP (1996) Organization of AMPA receptor subunits at a glutamate synapse: a quantitative immunogold analysis of hair cell synapses in the rat organ of Corti. J Neurosci 16:4457-4467.

Mayat E, Petralia RS, Wang Y-X, Wenthold RJ (1995) Immunoprecipitation, immunoblotting, and immunocytochemistry studies suggest that glutamate receptor $\delta$ subunits form novel postsynaptic receptor complexes. J Neurosci 15:2533-2546.

Nakagawa T, Komune S, Uemura T, Akaike N (1991) Excitatory amino acid response in isolated spiral ganglion cells of the guinea pig cochlea. J Neurophysiol 675:715-723.

Niedzielski AS, Wenthold RJ (1995) Expression of AMPA, kainate and NMDA receptor subunits in cochlear and vestibular ganglia. J Neurosci 15:2338-2353.

Niedzielski AS, Safieddine S, Wenthold RJ (1997) Molecular analysis of excitatory amino acid receptor expression in the cochlea. Audiol Neuro Otol 2:79-91.

Petralia RS (1997) Immunocytochemical localization of ionotropic glutamate receptors (GluRs) in neural circuits. In: The ionotropic gluta- 
mate receptors (Monaghan DT, Wenthold RJ, eds), pp 219-263. Totowa, NJ: Humana.

Petralia RS, Wenthold RJ (1992) Light and electron immunocytochemical localization of AMPA-selective glutamate receptors in the rat brain. J Comp Neurol 318:329-354.

Petralia RS, Yokotani N, Wenthold RJ (1994) Light and electron microscopic distribution of the NMDA receptor subunit, NR1, in the rat nervous system using a selective antipeptide antibody. J Neurosci 14:667-696.

Petralia RS, Wang Y-X, Zhao H-M, Wenthold RJ (1996) Ionotropic and metabotropic glutamate receptors show unique postsynaptic, presynaptic, and glial localizations in the dorsal cochlear nucleus. J Comp Neurol 372:356-383.

Puel J-L (1995) Chemical synaptic transmission in the cochlea. Prog Neurobiol 47:449-476.

Puel J-L, Ladrech S, Chabert R, Pujol R, Eybalin M (1991a) Electrophysiological evidence for the presence of NMDA receptors in the guinea pig cochlea. Hear Res 51:255-264.

Puel J-L, Pujol R, Ladrech S, Eybalin M (1991b) $\alpha$-Amino-3-hydroxy-5methyl-4-isoxazole propionic acid (AMPA) electrophysiological and neurotoxic effects in the guinea pig cochlea. Neuroscience 45:63-72.

Puel J-L, Pujol R, Tribillac R, Ladrech S, Eybalin M (1994) Excitatory amino acid antagonists protect cochlear auditory neurons from excitotoxicity. J Comp Neurol 341:241-256.

Pujol R, Carlier E, Devigne C (1978) Different patterns of cochlear innervation during development in the kittens. J Comp Neurol 117:529-536.

Pujol R, Puel J-L, Eybalin M (1992) Implication of non-NMDA and NMDA receptors in cochlear ischemia. NeuroReport 3:299-302.

Ryan AF, Schwartz IR, Helfert RH, Keithley E, Wang Z-X (1987) Selective retrograde labelling of lateral olivocochlear neurons in the brainstem based on preferential uptake of ${ }^{3} \mathrm{H}$-D-aspartic acid in the cochlea. J Comp Neurol 155:606-616.

Ryan AF, Brumm D, Kraft M (1991) Occurrence and distribution of non-NMDA glutamate receptor messenger RNAs in the cochlea. NeuroReport 2:643-646.

Safieddine S, Eybalin M (1992a) Triple immunofluorescence evidence for the coexistence of acetylcholine, enkephalins and calcitonin generelated peptide within efferent (olivocochlear) neurons of rats and guinea pigs. Eur J Neurosci 4:981-992.

Safieddine S, Eybalin M (1992b) Coexpression of NMDA and AMPA/ kainate receptor mRNAs in cochlear neurons. NeuroReport 3:1145-1148.

Safieddine S, Eybalin M (1995) Expression of mGluR1 $\alpha$ mRNA receptor in rat and guinea pig cochlear neurons. NeuroReport 7:193-196.

Safieddine S, Bartolami S, Wenthold RJ, Eybalin M (1996) Pre- and postsynaptic $\mathrm{m} 3$ muscarinic receptor mRNA in the rodent peripheral auditory system. Mol Brain Res 40:127-135.

Scarphone E, Demêmes D, Jahn R, De Camilli P, Sans A (1988) Secretory function of the vestibular nerve calyx suggested by presence of vesicles, synapsin I, and synaptophysin. J Neurosci 8:4640-4645.
Sewell WF, Morz EA (1987) Neuroactive substances in inner ear extracts. J Neurosci 7:2465-2475.

Shnerson A, Devigne A, Pujol R (1982) Age-related changes in the c57bl/6j mouse cochlea. II. Ultrastructural finding. Dev Brain Res 2:77-88.

Simmons DD, Manson-Gieseke L, Hendrix TW, Morris K, Williams S (1991) Postnatal maturation of spiral ganglion neurons: a horseradish peroxidase study. Hear Res 55:81-91.

Simmons DD, Mansdorf NB, Kim JH (1996) Olivocochlear innervation of inner and outer hair cells during postnatal maturation: evidence for a waiting period. J Comp Neurol 370:5551-5562.

Sobkowicz HM, Slapnick SM (1994) The efferents interconnecting auditory inner hair cells. Hear Res 75:81-92.

Soto E, Vega R (1988) Actions of excitatory amino acid agonist and antagonists on the primary afferents of the vestibular system of the axolotl. Brain Res 462:104-111.

Spoendlin H (1972) Innervation densities of the cochlea. Acta Otolaryngol 73:235-248.

Steinhauser C, Gallo V (1996) News on glutamate receptors in glial cells. Trends Neurosci 19:339-345.

Takayama C, Nakagawa S, Watanabe M, Mishina M, Inoue Y (1995) Light- and electron-microscopic localization of the glutamate receptor channel $\delta 2$ subunit in the mouse Purkinje cell. Neurosci Lett 188:89-92.

Takayama C, Nakagawa S, Watanabe M, Mishina M, Inoue Y (1996) Developmental changes in expression and distribution of the glutamate receptors channel $\delta 2$ subunit according to the Purkinje cell maturation. Dev Brain Res 92:147-155.

Towbin H, Staehelin T, Gordon J (1979) Electrophoretic transfer of proteins from polyacrylamide gels to nitrocellulose sheets: procedure and some applications. Proc Natl Acad Sci USA 76:4350-4354.

Usami S, Ottersen P (1995) Differential cellular distribution of glutamate and glutamine in the rat vestibular endorgans: an immunocytochemical study. Brain Res 676:285-292.

Wenthold RJ, Hunter C, Wada K, Deschesne CJ (1990) Antibodies to a C-terminal peptide of the rat brain glutamate receptor subunit, GluR-A, recognizes a subpopulation of AMPA binding sites but not kainate sites. FEBS Lett 276:147-150.

Wenthold RJ, Yokotani N, Doi K, Wada K (1992) Immunochemical characterization of the non-NMDA glutamate receptor using subunitspecific antibodies: evidence for a hetero-oligomeric structure in rat brain. J Biol Chem 267:501-507.

Wersäll J, Bagger-Sjöbäck D (1974) Morphology of the vestibular sense organ. In: Handbook of sensory physiology (Kornuber HH, ed), pp 123-170. New York: Springer.

Yamazaki M, Araki K, Shibata A, Mishina M (1992) Molecular cloning of a cDNA encoding a novel member of the mouse glutamate receptor channel family. Biochem Biophys Res Commun 183:886-892.

Zhao H-M, Wenthold RJ, Wang Y-X, Petralia RS (1997) $\delta$ Glutamate receptors are differentially distributed at parallel and climbing fiber synapses on Purkinje cells. J Neurochem 68:1041-1052. 